\title{
ESTRADIOL AND GNRH ON OVULATION INDUCTION FOR ESTRUS SYNCHRONIZED CROSSBRED COWS ${ }^{1}$
}

\author{
FABRÍCIO ALBANI OLIVEIRA ${ }^{2}$, ÍTALO CÂMARA DE ALMEIDA ${ }^{3 *}$, JURANDY MAURO PENITENTE FILHO ${ }^{4}$, \\ CIRO ALEXANDRE ALVES TORRES ${ }^{4}$
}

\begin{abstract}
Estradiol benzoate (EB), estradiol cypionate (EC), and gonadotrophin releasing hormone $(\mathrm{GnRH})$ were evaluated as ovulation inducers for TAI of crossbred lactating cows. In experiment I $(n=45)$, the follicular dynamics was evaluated, while in experiment II $(n=171)$ the reproductive efficiency was evaluated. All females were submitted to a synchronization protocol: insertion on day 0 (D0) of intravaginal progesteronerelease intravaginal device (PRID; $1 \mathrm{~g}$ ) plus administration of EB 2mg; D8, PRID removal, administration of $0.150 \mathrm{mg}$ PGF2 $\alpha$ and $400 \mathrm{IU}$ of eCG, and cows were allocated into three treatments: 1) TEB9 - IM administration of $1 \mathrm{mg}$ EB on D9 and AI performed 52 hours after PRID removal; 2) TEC - IM administration of 1mg EC on D8 and AI performed 48 hours after withdrawal of PRID; and 3) TGnRH - administration of $100 \mu \mathrm{g}$ GnRH on D10 and AI performed 52 hours after removal of PRID. The follicular growth rate was lower in the EC group $(p<0.05)$. There was no effect of treatments on ovulation and pregnancy rates $(p>0.05)$. The use of EB, EC, and GnRH as ovulation inducers in the TAI protocol did not show marked differences in the evaluated patterns of follicular dynamics and pregnancy.
\end{abstract}

Keywords: Biotechnology. Estradiol benzoate (EB). Estradiol cypionate (EC). Reproduction.

\section{ESTRADIOL E GNRH NA SINCRONIZAÇÃO DO ESTRO E INDUÇÃO DA OVULAÇÃO DE VACAS MESTIÇAS}

\begin{abstract}
RESUMO - Benzoato de estradiol (EB), cipionato de estradiol (EC) e hormônio liberador de gonadotrofinas $(\mathrm{GnRH})$ foram avaliados como indutores da ovulação na IATF em vacas mestiças em lactação. No experimento I $(n=45)$ a dinâmica folicular foi avaliada, enquanto no experimento II $(n=171)$ a eficiência reprodutiva foi avaliada. Todas as fêmeas foram submetidas a um protocolo de sincronização: inserção no dia 0 (D0) de dispositivo intravaginal de liberação de progesterona (PRID; 1g) mais administração de EB 2mg; D8, remoção de PRID, administração de 0,150mg de PGF2 $\alpha$ e 400 UI de eCG, e as vacas foram alocadas em três tratamentos: 1) TEB9 - administração IM de 1mg EB em D9 e AI realizada 52 horas após a remoção PRID; 2) TEC - administração IM de 1mg EC em D8 e AI realizada 48 horas após a remoção de PRID; e 3) TGnRH administração de $100 \mu \mathrm{g}$ GnRH em D10 e AI realizada 52 horas após a remoção de PRID. A taxa de crescimento folicular foi menor no grupo EC $(p<0,05)$. Não houve efeito dos tratamentos nas taxas de ovulação e prenhez ( $p>0,05)$. O uso de EB, EC e GnRH como indutores de ovulação em protocolos de IATF não mostrou diferenças marcantes nos padrões avaliados de dinâmica folicular e prenhez.
\end{abstract}

Palavras-chave: Biotecnologia. Benzoato de estradiol (EB). Cipionato de estradiol (EC). Reprodução.

\footnotetext{
${ }^{*}$ Corresponding author

${ }^{1}$ Received for publication in $01 / 24 / 2020$; accepted in 04/13/2020.

Paper extracted from the doctoral thesis of the first author.

${ }^{2}$ General Coordination of Field Management, Instituto Federal do Espírito Santo, Alegre, ES, Brazil; falboli@hotmail.com - ORCID: 0000 $-0002-1707-9371$.

${ }^{3}$ Department of Veterinary Medicine, Universidade Federal do Espírito Santo, Alegre, ES, Brazil; almeidaicvet@gmail.com - ORCID: 0000-0002-3349-1796.

${ }^{4}$ Department of Animal Science, Universidade Federal de Viçosa, Viçosa, MG, Brazil; penitentefilho@yahoo.com.br - ORCID: 0000-0002 -8592-4020, cirotorres11@gmail.com - ORCID: 0000-0003-3043-8938.
} 


\section{INTRODUCTION}

The tropical dairy herd is basically composed of crossbred cattle, mainly because it is a viable alternative for many production systems that seek to reduce the cost of production from animals kept under grazing conditions. This is possible since crossbred cattle have desirable characteristics as a consequence of their heterosis, which results in animals with robustness, productivity, and adaptation to the environmental limitations observed in most dairy farms in tropical countries. However, despite the improvement of the crossbred animals due to heterosis, they still require appropriate handling and feed management practices (MADALENA; PEIXOTO; GIBSON, 2012).

Synchronization treatments of ovulation based on the use of progesterone simultaneous to the use of estrogen have presented improvements in the pregnancy rate in both anestrous and cycling cows (AYRES et al., 2008; SÁ FILHO et al., 2009; COLAZO et al., 2013; VASCONCELOS et al., 2018). These protocols have been successfully used to control the follicular and luteal dynamics, and also in ovulation synchronizing, allowing artificial insemination (AI) without estrus detection (SÁ FILHO et al., 2009; BÓ et al., 2016).

Estradiol benzoate (EB) has been commonly used as an ovulation inducer in association with synchronization treatment based on progesterone and estrogen for Bos taurus taurus (MARTINEZ et al., 2002; COLAZO et al., 2013; MELO et al., 2016), Bos taurus indicus (SÁ FILHO et al., 2009), and Bos taurus taurus $\mathrm{x}$ Bos taurus indicus (ALMEIDA et al., 2016a). In all cases, EB is administered $24 \mathrm{~h}$ after removal of the progesterone device; thus, requiring to submit females to four managements during the synchronization protocol.

Additionally, other inducers have been effectively used, such as estradiol cypionate (EC) in Bos taurus indicus (SÁ FILHO et al., 2009; MENEGHETTI et al., 2009; SÁ FILHO et al., 2010; SARTORI; MONTEIRO JR.; WILTBANK, 2016) and gonadotropin releasing hormone $(\mathrm{GnRH})$ in $B o s$ taurus taurus. EC can be used at the same time as the removal of the progesterone device and the GnRH can be administered during AI (GOTTSCHALL et al., 2012; ALMEIDA et al., 2016a). The replacement of EB by EC or GnRH is reliable as long as it does not compromise the timed artificial insemination (TAI) efficiency since it reduces the labor during the protocol.

In this context, this study aimed to evaluate the efficiency of EB, EC, and GnRH as ovulation inducers in TAI protocols for crossbred dairy cattle.

\section{MATERIAL AND METHODS}

The experiment was carried out from October, 2014 to April, 2015, on a commercial farm located in the municipality of Dores do Rio Preto, state of Espirito Santo, Brazil, at the geographic coordinates $20^{\circ} 41^{\prime}$ 'South, $41^{\circ} 50^{\prime}$ ' West and $774 \mathrm{~m}$ altitude. The farm is located in a region with hot/ rainy summers, and cold/dry winters, with average annual temperature of $19.2^{\circ} \mathrm{C}$ and annual rainfall of $1,000 \mathrm{~mm}$.

A total of 216 milking crossbred cows (Bos taurus indicus x Bos taurus taurus) within the first and fourth lactation were selected based on their high fertility background and lack of clinical conditions of infectious or metabolic diseases, retention of placenta, or changes on genitals at gynecological examination. Cows were kept on Brachiaria brizantha $\mathrm{cv}$. Marandu pasture and supplemented with mineral mixture ad libitum, and concentrate containing $22 \%$ of crude protein at $1 \mathrm{~kg} / 3 \mathrm{~L}$ of produced milk.

During the application of progesteronerelease intravaginal device (PRID) the postpartum period related to the day of the beginning of the timed artificial insemination (TAI) protocol (day 0) was recorded. Milk production, cows body weight (BW), and body condition score (BCS, ranging from 1 to 5) were also measured as described by Edmonson et al. (1989). Cows were uniformly divided into groups based on their parturition order, milk production, and $\mathrm{BCS}$.

Two experiments were performed; the follicle dynamics was evaluated in experiment I $(n=45)$, while the reproductive efficiency of the cows was evaluated in experiment II $(\mathrm{n}=171)$.

All animals were submitted to a synchronizing protocol: day 0 (D0), insertion of progesterone-release intravaginal device (PRID; 1g; CRONIPRESS $^{\circledR}$, Biogénesis-Bagó, Argentina) plus administration, intramuscular (IM), of $2 \mathrm{mg}$ estradiol benzoate (EB; BIOESTROGEN ${ }^{\circledR}$, Biogénesis-Bagó, Argentina); day 8 (D8), PRID removal and administration, IM, of $0.15 \mathrm{mg}$ prostaglandine $\mathrm{F}_{2 \alpha}$ $\left(\mathrm{PGF}_{2 \alpha}\right.$; CRONIBEN $^{\circledR}$, Biogénesis-Bagó, Argentina), and 400 UI equine chorionic gonadotropin (eCG; SINCRO ECG®, Ouro Fino, Brasil). On D8 cows were assigned to three treatments: 1) TEB9 - $1 \mathrm{mg}$ $\mathrm{EB}$, IM, on day 9 and AI was performed $52 \mathrm{~h}$ after the PRID removal (SOBREIRA et al., 2017); 2) TEC - $1 \mathrm{mg}$ estradiol cypionate (EC; CRONI-CIP ${ }^{\circledR}$, Biogénesis-Bagó, Argentina), IM, on D8 and AI was performed $48 \mathrm{~h}$ after PRID removal (SOBREIRA et

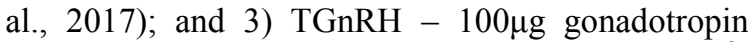
releasing hormone $\left(\mathrm{GnRH}\right.$; $\mathrm{GONAXAL}^{\circledR}$, 
Biogénesis-Bagó, Argentina), IM, on day 10 and AI was performed $52 \mathrm{~h}$ after PRID removal (ALMEIDA et al., 2016a).

Ultrasonography evaluations were performed at 7 days before the start of synchronization treatment, days 0,8 , and on day of TAI. On day TAI, the follicle dynamics was also evaluated every 12 hours until ovulation, which was determined by the lack of the dominant follicle. Follicles were classified according to their diameter as small $(<6$ $\mathrm{mm}$ ), medium (6 to $8 \mathrm{~mm}$ ), and dominant ( $\mathrm{DF}>8$ $\mathrm{mm})$. Growth index ( $\mathrm{mm} /$ day) was then calculated by the difference between the follicular diameter on days 10 and 8 .

In experiment II, cows were assigned to treatments as in experiment I: TEB9 $(\mathrm{n}=61)$, TEC $(\mathrm{n}=58)$, and TGnRH $(\mathrm{n}=52)$. Cows were artificially inseminated by the same technician with semen from crossbred bulls, which was obtained from the Brazilian Association of Artificial Insemination.

Pregnancy diagnosis was performed 30 days after AI by ultrasonography; pregnancy was determined by presence of embryonic vesicle. Pregnancy rate was determined for each treatment by dividing the number of pregnant cows by the number of cows within the treatment.

For data analyses, the Statistical Analyses System was used. Data on the number of small, medium, and large follicles, total of follicles, diameter of largest follicle, follicular growth rate, and interval from PRID removal to ovulation and TAI were analyzed by ANOVA with mean comparison by Tukey's test, considering the effects of treatment and day of observation, by using PROC GLM.
A logistic regression analysis was performed using $\mathrm{R}$ software for evaluating the effects of body condition score on pregnancy rate. Data of pregnancy rate was organized in contingency tables and analyzed by Chi-square test $\left(\chi^{2}\right.$ g11 $=3.84 ; P=$ $0.05)$. The significance level adopted was $\alpha=0.05$.

\section{RESULTS AND DISCUSSION}

Cows had average body weight (BW) of $412.98 \pm 1.99 \mathrm{~kg}$, average body condition score (BCS) of $2.43 \pm 0.03$, average postpartum days of $95.07 \pm 1.56$, and average daily milk production of $9.79 \pm 1.22$ liters.

There was no interaction between days of observation and treatments for the number and size of follicles ( $p>0.05$; Table 1$)$. However, on day 10 a greater number of large follicles were observed compared to the observations of day 0 for all treatments $(p<0.05)$. These results demonstrate that the improvement in physiological conditions, induced by the synchronization protocol using estradiol and progesterone in cycling and in anestrous cows, has led to an increase of the number of growing follicles as a result of the synchronization of the emergence of a new follicular wave in dairy cows. It can thus be inferred that the protocols used in this study with dairy cows, as well as those found in the literature with beef cows, have satisfactory effects on controlling follicular and luteal dynamics and ovulation synchronization, allowing timed artificial insemination (TAI) without previous estrus detection (BARUSELLLI et al., 2004; BÓ et al., 2007; SÁ FILHO et al., 2009; RICCI et al., 2017).

Table 1. Number of smaller than $6 \mathrm{~mm}, 6$ to $8 \mathrm{~mm}$, and greater than $8 \mathrm{~mm}$ follicles, on days 0 , 8 , and 10, according to treatments (Mean \pm standard error mean).

\begin{tabular}{|c|c|c|c|c|}
\hline \multirow[b]{2}{*}{ Item } & \multicolumn{3}{|c|}{ Number of follicles } & \multirow[b]{2}{*}{ Total } \\
\hline & $<6 \mathrm{~mm}$ & 6 to $8 \mathrm{~mm}$ & $>8 \mathrm{~mm}$ & \\
\hline \multicolumn{5}{|c|}{ TREATMENT } \\
\hline TGnRH & $11.9 \pm 1.1^{\mathrm{a}}$ & $0.7 \pm 0.1^{\mathrm{a}}$ & $0.6 \pm 0.1^{\mathrm{a}}$ & $13.2 \pm 1.1^{\mathrm{a}}$ \\
\hline TEB9 & $11.2 \pm 0.9^{\mathrm{a}}$ & $0.5 \pm 0.1^{\mathrm{a}}$ & $0.8 \pm 0.1^{\mathrm{a}}$ & $12.4 \pm 0.9^{\mathrm{a}}$ \\
\hline TEC & $13.7 \pm 1.0^{\mathrm{a}}$ & $0.6 \pm 0.1^{\mathrm{a}}$ & $0.7 \pm 0.1^{\mathrm{a}}$ & $15.1 \pm 1.0^{\mathrm{a}}$ \\
\hline \multicolumn{5}{|c|}{ DAY } \\
\hline 0 & $12.0 \pm 1.2^{\mathrm{b}}$ & $0.8 \pm 0.1^{\mathrm{a}}$ & $0.2 \pm 0.1^{\mathrm{b}}$ & $13.0 \pm 1.2^{\mathrm{a}}$ \\
\hline 8 & $12.4 \pm 1.0^{\mathrm{a}}$ & $0.7 \pm 0.2^{\mathrm{a}}$ & $0.9 \pm 0.1^{\mathrm{a}}$ & $14.0 \pm 1.1^{\mathrm{a}}$ \\
\hline 10 & $12.5 \pm 0.8^{\mathrm{a}}$ & $0.2 \pm 0.1^{\mathrm{b}}$ & $1.0 \pm 0.1^{\mathrm{a}}$ & $13.8 \pm 0.8^{\mathrm{a}}$ \\
\hline
\end{tabular}

TGnRH = treatment with GnRH; TEB9 = treatment with EB; TEC = treatment with EC. Means lacking a common superscript letter within a column differ by Tukey's test $(\mathrm{p}<0.05)$. 
No differences were observed among the ovulation inductors for the interval between the TAI and ovulation ( $\mathrm{p}>0.05)$. Nevertheless, cows treated with GnRH showed an interval from PRID removal to ovulation greater than EC treated cows $(p<0.05$;
Table 2). In this context, Ferreira et al. (2017) also found a longer time for ovulation, after removing the PRID, when using GnRH $(77.3 \pm 3.0$ h) or EC $(71.3$ $\pm 2.9 \mathrm{~h}$ ) as ovulation inducers in dairy cows.

Table 2. Follicular growth rate and interval from PRID removal to TAI and ovulation according to treatments (Mean \pm standard error of mean).

\begin{tabular}{cccc}
\hline \multirow{2}{*}{ Treatment } & $\begin{array}{c}\text { Follicular growth rate } \\
(\mathrm{mm} / \text { day) }\end{array}$ & \multicolumn{2}{c}{ Interval to ovulation } \\
\cline { 3 - 4 } & $1.9 \pm 0.2^{\mathrm{a}}$ & $66.7 \pm 1.3^{\mathrm{a}}$ & TAI $(\mathrm{h})$ \\
\hline TGnRH & $1.5 \pm 0.2^{\mathrm{a}}$ & $64.4 \pm 0.7^{\mathrm{ab}}$ & $14.8 \pm 1.5^{\mathrm{a}}$ \\
TEB9 & $0.7 \pm 0.2^{\mathrm{b}}$ & $61.4 \pm 1.0^{\mathrm{b}}$ & $12.4 \pm 0.7^{\mathrm{a}}$ \\
TEC & $1.4 \pm 0.1$ & $63.1 \pm 0.6$ & $12.8 \pm 1.2^{\mathrm{a}}$ \\
Mean & & $13.2 \pm 0.6$ \\
\hline
\end{tabular}

$\mathrm{TGnRH}=$ treatment with GnRH; TEB9 $=$ treatment with EB; TEC $=$ treatment with EC. Means lacking a common superscript letter within a column differ $(\mathrm{p}<0.05)$.

A beneficial effect of the addition of GnRH in estradiol-based TAI protocols was expected. The initial hypothesis was that GnRH could reduce the spread of ovulation (Figure 1) and consequently improve the rate of ovulation and pregnancy (Table 4), which did not happen. The use of GnRH promotes a suddenly increase of LH levels, which reaches a peak within 2 hours resulting in ovulation after 24 hours approximately. Administration of EC leads to a peak of LH within 45.0 to 54.6 hours after its use (SALES et al., 2012), and the treatment with EB leads to a peak of LH within 19.6 to 21.5 hours after its administration (MARTINEZ et al., 2002; SALES et al., 2016).

The difference among estrogens in time for LH peak occurs due to the differences in their physiological life time; EC has low water-solubility and consequently, slow release leading to prolonged biological activity when compared to EB. The period of time from PRID removal to ovulation was greater for GnRH treatment than EC due to the difference from the time of its administration and to the time for induction and LH peak (SALES et al., 2012; FERREIRA et al., 2017).

There were no differences for period of time from AI to ovulation, and ovulation rates among treatments ( $p>0.05$; Figure 1). But as can be observed, cows treated with EC showed two ovulation peaks and consequently the AI occurred in two moments. Unlike cows treated with GnRH or $\mathrm{EB}$, where inseminations were concentrated around
$12 \mathrm{~h}$ after ovulation. This can be explained by the anticipation of EC administration and the delay of the GnRH administration compared to EB, since EC takes longer to achieve its effect when compared to the other two drugs. In another study, Ferreira et al. (2017) also found no effect of the use of EC or GnRH on the dispersion of ovulation.

It has been reported that the ideal moment to obtain high fertility rates may vary from 12 to 24 hours before ovulation (ROELOFS et al., 2006), or result in a higher probability of pregnancy if performed closer to estrus, approximately 6 hours after detection to estrus (NELSON et al., 2017). Therefore, it can be inferred that the interval from AI to ovulation remained an appropriate time to obtain high pregnancy rates.

Follicle growth rate was lower for EC treatment $(p<0.05$; Table 2). Administration of exogenous estrogen at the PRID removal can decrease follicular growth rate (AYRES et al., 2008; VASCONCELOS et al., 2018). The follicular growth rate observed in the current study was similar to those observed in studies using ovulationsynchronizing protocols which were 1.3 to $1.8 \mathrm{~mm} /$ day in Bos taurus taurus and $1.4 \mathrm{~mm} /$ day in Bos taurus indicus (COLAZO; AMBROSEA, 2011). In contrast, other studies have indicated lower follicular growth rates in crossbred heifers treated with $\mathrm{EB}$ and EC, with $0.89 \pm 0.26$ and $0.81 \pm 0.63 \mathrm{~mm} /$ day, respectively (SOBREIRA et al., 2017). 


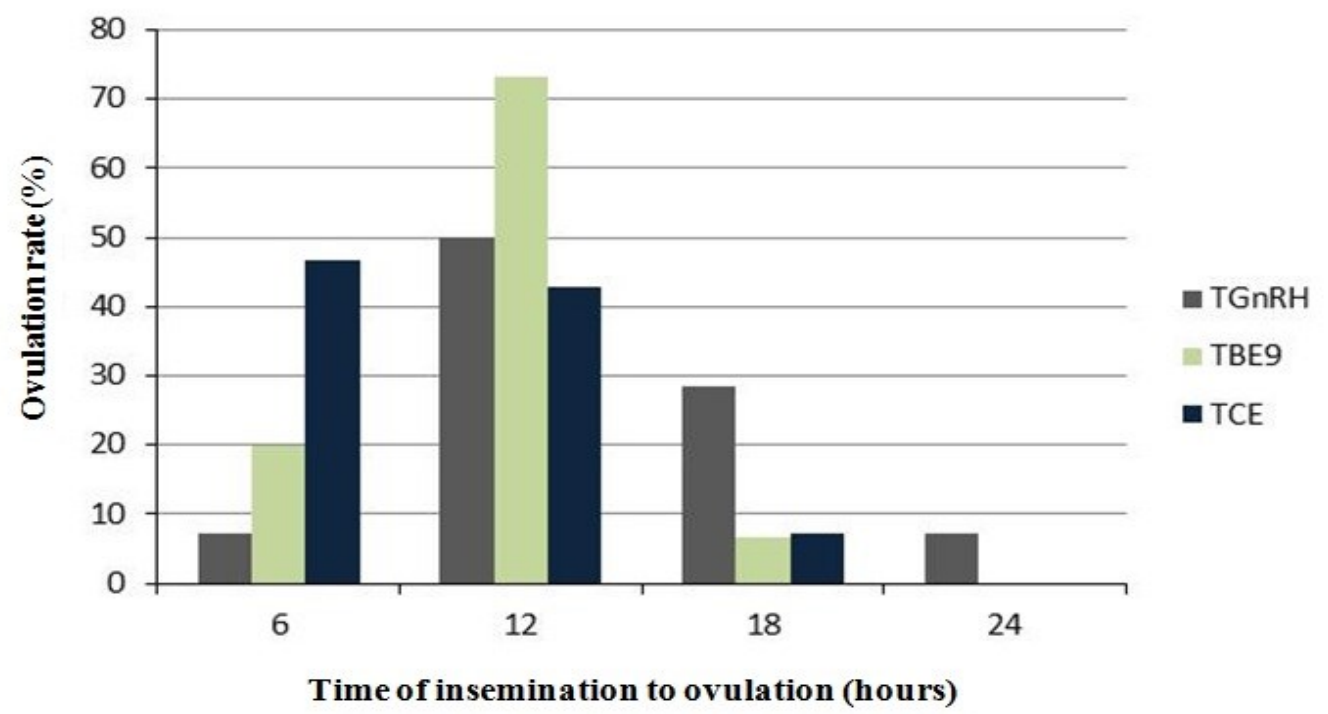

Figure 1. Dispersion of ovulations after artificial insemination according to treatments with GnRH (TGnRH), BE9 (TBE9), and CE (TCE) $(p>0.05)$.

There was no interaction between treatments and day of observation for diameter of the largest follicle ( $p>0.05$; Table 3$)$. The importance of the ovulatory follicle diameter in TAI remains in the fact that it is related to the size of the corpus luteum in the posterior diestrum, and also because it is highly correlated to the progesterone secretion which is essential for embryo development (VASCONCELOS et al., 2011; PINAFFI et al., 2015).

In this context, similar results were found in other studies with Holstein cows, where the diameter of the follicle on the $8^{\text {th }}$ day was 11.2 and $11.9 \mathrm{~mm}$ for cows treated with EC and $\mathrm{GnRH}$, respectively (FERREIRA et al., 2017). A satisfactory rate of follicular growth was observed on the $10^{\text {th }}$ day of the present study, corroborating the observation of other studies (SÁ FILHO et al., 2010; SÁ FILHO et al., 2011; SALES et al., 2012; ALMEIDA et al., 2016b; SOBREIRA et al., 2017). According to Sartori et al. (2001), follicles acquire ovulatory ability with approximately $10 \mathrm{~mm}$ of diameter. Thus, the three experimental treatments of the present study had follicles with ovulatory size. In this context, a difference was reported $(\mathrm{p}<0.05)$ between mean follicular diameter in pregnant $(11.53 \pm 0.32 \mathrm{~mm})$ and nonpregnant $(10.16 \pm 0.35 \mathrm{~mm})$ cows suggesting a relation between dominant follicle diameter at AI (KAPSE et al., 2017).

Table 3. Diameter of the largest follicle according to treatments on days 8 and 10 (Mean \pm standard error mean).

\begin{tabular}{|c|c|c|c|}
\hline \multicolumn{3}{|c|}{ Diameter $(\mathrm{mm})$ of the largest follicle } & $p$-value \\
\hline TGnRH & TEB9 & TEC & \multirow{2}{*}{0.4605} \\
\hline $10.7 \pm 0.5^{\mathrm{a}}$ & $11.4 \pm 0.5^{\mathrm{a}}$ & $11.0 \pm 0.4^{\mathrm{a}}$ & \\
\hline $\begin{array}{c}\text { Day 8 } \\
9.7 \pm 0.3^{\mathrm{b}}\end{array}$ & & $\begin{array}{c}\text { Day 10 } \\
12.5 \pm 0.3^{\mathrm{a}}\end{array}$ & $<0.0001$ \\
\hline
\end{tabular}

TGnRH $=$ treatment with GnRH; TEB9 $=$ treatment with EB; TEC $=$ treatment with EC. Means lacking a common superscript letter within a row differ $(\mathrm{p}<0.05)$. 
There was no difference among treatments for ovulation and pregnancy rates ( $p>0.05$; Table 4$)$. Ferreira et al. (2017) also found no differences in ovulation rates when comparing EC $(83.3 \%)$ and GnRH $(85.0 \%)$ in dairy cows. In contrast, Bandai et al. (2020) found significant differences when evaluating EB and GnRH in the pregnancy rate of dairy cows, with 56.6 and $29.8 \%$ respectively. Values lower than the pregnancy rates found in the present study.

Table 4. Pregnancy and ovulation rates according to treatments with GnRH, EB9, and EC.

\begin{tabular}{ccc}
\hline Treatment & Ovulation rate $(\%)$ & Pregnancy rate $(\%)$ \\
TGnRH & $93.3(14 / 15)^{\mathrm{a}}$ & $51.9(27 / 52)^{\mathrm{a}}$ \\
TEB9 & $100.0(15 / 15)^{\mathrm{a}}$ & $62.3(38 / 61)^{\mathrm{a}}$ \\
TEC & $93.3(14 / 15)^{\mathrm{a}}$ & $37.9(22 / 58)^{\mathrm{a}}$ \\
Mean & $95.6(43 / 45)^{\mathrm{a}}$ & $50.9(87 / 171)^{\mathrm{a}}$ \\
\hline
\end{tabular}

$\mathrm{TGnRH}=$ treatment with $\mathrm{GnRH}$; TEB9 $=$ treatment with EB; TEC $=$ treatment with EC. $(\mathrm{p}>0.05)$.

Although there are pharmacological differences among estradiol esters and GnRH, both had great efficiency as ovulation inductors, and also for ovulation synchronizing (Figure 1). Protocols for synchronization of ovulation based on progesterone and estrogen have been found to be efficient to induce ovulation as reported by several studies (AYRES et al., 2008; SÁ FILHO et al., 2010; SALES et al., 2012; ALMEIDA et al., 2016b; SOBREIRA et al., 2017). Drugs used in this study were efficient to induce LH peak, which resulted in synchronized ovulations.

The administration of eCG decreases variation in the moment of ovulation and increases ovulation rate, which would explain the similarity of the treatments in this study. The eCG enhances the estradiol production by follicles, and also increases estradiol levels for all treatments. Consequently, cows had greater estrous activity regardless of the ovulation inductor (SÁ FILHO et al., 2010; SALES et al., 2016).

The pregnancy rate observed in this study was satisfactory, above 50\% (ALMEIDA et al., 2016a; ALMEIDA et al., 2016b). The insertion of PRID led to an increase of P4 levels during follicular development, which decreases LH pulses and improves the dominant follicle competence, quality of ovulated oocyte, and quality of uterine environment (PULLEY et al., 2013).

Both exogenous estrogens EC and EB, administered at the moment or $24 \mathrm{~h}$ after PRID removal, are efficient for increasing the proportion of cows showing estrus before TAI, and increasing pregnancy rate in Bos taurus indicus (SÁ FILHO et al., 2011), Bos taurus taurus (GOTTSCHALL et al., 2012), and crossbred cows (BARBOSA et al., 2011; SOBREIRA et al., 2017). Another factor that may also be a reason for the increase of pregnancy rates due to administration of exogenous estrogen is the greater exposure of the estrogen during the proestrus to improve fertilization and also influence the endometrial morphology, preparing the uterus for the next luteal phase. Such a scenario may be important for induction of progesterone receptors in the endometrium and to avoid a premature luteolysis and short cycles (CERRI et al., 2009; SÁ FILHO et al., 2011).

Administration of $\mathrm{GnRH}$ increased the synchrony of ovulation and pregnancy rates of cows submitted to TAI (SÁ FILHO et al., 2010). This improvement is likely due to two factors: (1) induction of a uniform preovulatory LH peak, and (2) anticipation of ovulation. Higher pregnancy rates were found in other studies with the increase in $\mathrm{GnRH}$ in the IATF protocols (ALMEIDA et al., 2016a).

Additionally, the influence of the body condition score on pregnancy rate was evaluated and no effects of BCS were observed on pregnancy rate ( $p>0.05$; Figure 2). Previous studies have shown that an increase in BCS leads to an increase in pregnancy rate of Bos taurus taurus (GOTTSCHALL et al., 2012) and Bos taurus indicus cows (MENEGHETTI et al., 2009; SÁ FILHO et al., 2010; PEREIRA et al., 2018). 


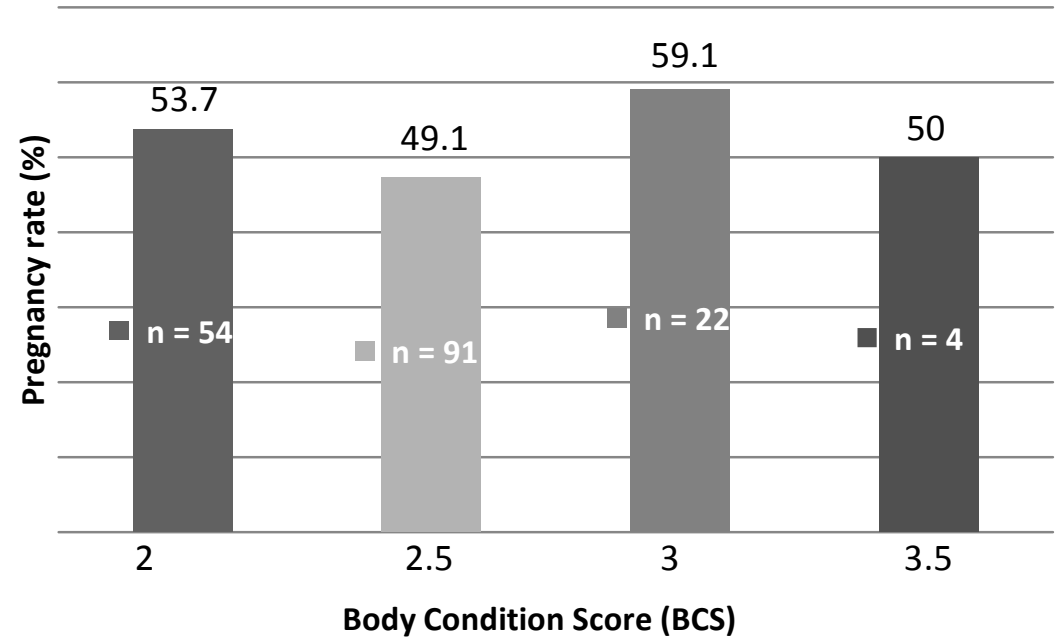

Figure 2. Pregnancy rate according to Body Condition Score $(\mathrm{p}>0.05)$.

The eCG provides gonadotrophic support for final follicular development (SÁ FILHO et al., 2010) being effective in enhancing dominant follicle growth rate, diameter of dominant follicle at TAI, ovulation rate (BARUSELLLI et al., 2004; BÓ et al., 2007; SÁ FILHO et al., 2009), P4 levels during the posterior diestrum (SOUZA et al., 2009; SÁ FILHO et al. 2010), and to enhance pregnancy rates, mainly in anestrous females, with low BCS, and few days postpartum (SÁ FILHO; DIAS; VASCONCELOS, 2006; AYRES et al., 2008; MARQUES; BARCELLOS; McMANUS, 2011; VASCONCELOS et al., 2018).

Although there are pharmacological differences among the evaluated ovulation inductors, all of them were efficient in synchronizing ovulation and achieving adequate fertility of crossbred lactating cows. However, utilization of EC or GnRH allows a reduction in the number of times that cows must be managed without decreasing fertility.

\section{CONCLUSION}

Administration of different ovulation inductors, estradiol benzoate, estradiol cypionate, and GnRH in timed artificial insemination protocols for crossbred cows does not alter the patterns of follicular dynamics and pregnancy rate.

\section{ACKNOWLEDGEMENTS}

The Conselho Nacional de Desenvolvimento Científico e Tecnológico (CNPq) - Brazil (142545/2009-0) and Coordenação de Aperfeiçoamento de Pessoal de Nível Superior (CAPES) - Brazil, for the financing of the project and granting scholarship. The Federal University of Viçosa and in particular the Department of Animal Science for the opportunity to carry out this study.

\section{REFERENCES}

ALMEIDA, I. C. et al. Pregnancy rates in dairy cows after the use of hormonal protocols of timed artificial insemination. Revista Brasileira de Ciências Veterinárias, 23: 99-103, 2016a.

ALMEIDA, I. C. et al. Pre-synchronization protocol in crossbred cows in the postpartum period. Revista Brasileira de Medicina Veterinária, 38: 353-357, 2016b.

AYRES, H. et al. Effect of timing of estradiol benzoate administration upon synchronization of ovulation in suckling Nelore cows (Bos indicus) treated with a progesterone-releasing intravaginal device. Animal Reproduction Science, 109: 77-87, 2008.

BANDAI, K. et al. A simple and practical short-term timed artificial insemination protocol using estradiol benzoate with prostaglandin F2 $\alpha$ in lactating dairy cows. Theriogenology, 141: 197-201, 2020.

BARBOSA, C. F. et al. Inseminação artificial em tempo fixo e diagnóstico precoce de gestação em vacas leiteiras mestiças. Revista Brasileira de Zootecnia, 40: 79-84, 2011.

BARUSELLI, P. S. et al. The use of hormonal treatments to improve reproductive performance of anestrous beef cattle in tropical climates. Animal Reproduction Science, 82: 479-486, 2004.

BÓ, G. A. et al. Technologies for fixed-time artificial insemination and their influence on reproductive performance of Bos indicus cattle. Society for Reproduction and Fertility, 64: 223236, 2007. 
BÓ, G. A. et al. Alternative programs for synchronizing and resynchronizing ovulation in beef cattle. Theriogenology, 86: 388-396, 2016.

CERRI, R. L. A. et al. Progesterone concentration, follicular development and induction of cyclicity in dairy cows receiving intravaginal progesterone inserts. Animal Reproduction Science, 110: 56-70, 2009.

COLAZO, M. G.; AMBROSEA, D. J. Neither duration of progesterone insert nor initial GnRH treatment affected pregnancy per timed-insemination in dairy heifers subjected to a Co-synch protocol. Theriogenology, 76: 578-588, 2011.

COLAZO, M. G. et al. Progesterone supplementation before timed AI increased ovulation synchrony and pregnancy per AI, and supplementation after timed AI reduced pregnancy losses in lactating dairy cows. Theriogenology, 79: 833-841, 2013.

FERREIRA, R. M. et al. Inducing ovulation with estradiol cypionate allows flexibility in the timing of insemination and removes the need for gonadotrophin-releasing hormone in the timed AI protocols for dairy cows. Reproduction, Fertility and Development, 29: 468-475, 2017.

GOTTSCHALL, C. S. et al. Avaliação do desempenho reprodutivo de vacas de corte lactantes submetidas à IATF apartir da aplicação do GnRH, da manifestação estral, da reutilização de dispositivos. Acta Scientiae Veterinariae, 40: 1-10, 2012.

KAPSE, S. et al. Dominant follicle diameter at insemination is related to positive pregnancy outcome in dairy cattle. Indian Journal of Animal Reproduction, 38: 56-57, 2017.

MADAlENA, F. E.; PEIXOTO, M. G. C. D.; GIBSON, J. Dairy cattle genetics and its applications in Brazil. Livestock Research for Rural Development, 24: 1-49, 2012.

MARTINEZ, M. F. et al. The use of a progesteronereleasing device (CIDR-B) or melengestrol acetate with GnRH, LH, or estradiol benzoate for fixed-time $\mathrm{AI}$ in beef heifers. Journal of Animal Science, 80: 1746-1751, 2002.

MARQUES, P. R.; BARCELLOS, J. O. J; McMANUS, C. Competitiveness of beef farming in Rio Grande do Sul State, Brazil. Agricultural Systems, 104: 689-693, 2011.

MELO, L. F. et al. Progesterone-based fixed-time artificial insemination protocols for dairy cows: Gonadotropin-releasing hormone versus estradiol benzoate at initiation and estradiol cypionate versus estradiol benzoate at the end. Journal of Dairy Science, 99: 9227-9237, 2016.

MENEGHETTI, M. et al. Fixed-time artificial insemination with estradiol and progesterone for Bos indicus cows I: Basis for development of protocols. Theriogenology, 72: 179-189, 2009.

NELSON, S. T. et al. Automated activity monitoring and visual observation of estrus in a herd of loose housed Hereford cattle: Diagnostic accuracy and time to ovulation. Theriogenology, 87: 205-211, 2017.

PEREIRA, L. L. et al. Effect of body condition score and reuse of progesterone-releasing intravaginal devices on conception rate following timed artificial insemination in Nelore cows. Reproduction in Domestic Animals, 53: 624-628, 2018.

PINAFFI, F. L. V. et al. Follicle and corpus luteum size and vascularity as predictors of fertility at the time of artificial insemination and embryo transfer in beef cattle. Pesquisa Veterinária Brasileira, 35: 470-476, 2015.

PULLEY, S. L. et al. Ovarian characteristics, serum concentrations of progesterone and estradiol, and fertility in lactating dairy cows in response to equine chorionic gonadotropin. Theriogenology, 79: 127134,2013

RICCI, A. et al. Characterization of luteal dynamics in lactating Holstein cows for 32 days after synchronization of ovulation and timed artificial insemination. Journal of Dairy Science, 100: 98519860, 2017

ROELOFS, J. B. et al. Effects of insemination ovulation interval on fertilization rates and embryo characteristics in dairy cattle. Theriogenology, 66: 2173-2181, 2006.

SÁ FILHO, M. F. et al. Equine chorionic gonadotropin improves the efficacy of a progestinbased fixed-time artificial insemination protocol in Nelore (Bos indicus) heifers. Animal of Reproduction Science, 118: 182-187, 2010.

SÁ FILHO, M. F. et al. Importance of estrus on pregnancy per insemination in suckled Bos indicus cows submitted to estradiol/progesterone-based timed insemination protocols. Theriogenology, 76 : 455-463, 2011.

SÁ FILHO, O. G.; DIAS, C. C.; VASCONCELOS, J. L. M. Effect of progesterone or $17 \beta$ - estradiol on luteal lifespan in anoestrous Nelore cows. Journal Animal Science, 84: 207-207, 2006. 
SÁ FILHO, O. G. et al. Fixed-time artificial insemination with estradiol and progesterone for Bos indicus cows II: Strategies and factors affecting fertility. Theriogenology, 72: 210-218, 2009.

SALES, N. S. et al. Effects of two estradiol esters (benzoate and cypionate) on the induction of synchronized ovulations in Bos indicus cows submitted to a timed artificial insemination protocol. Theriogenology, 78: 510-516, 2012.

SALES, J. N. et al. Effects of eCG are more pronounced in primiparous than multiparous Bos indicus cows submitted to a timed artificial insemination protocol. Theriogenology, 86: 22902295, 2016.

SARTORI, R. et al. Follicular deviation and acquisition of ovulatory capacity in bovine follicles. Biology of Reproduction, 65: 1403-1409, 2001.

SARTORI, R.; MONTEIRO JR., P. L. J.; WILTBANK, M. C. Endocrine and metabolic differences between Bos taurus and Bos indicus cows and implications for reproductive management. Animal Reproduction Science, 13: 168-181, 2016.

SOBREIRA, R. R. et al. Estradiol cypionate and estradiol benzoate in artificial insemination protocols in fixed time in crossbred heifers. Veterinária e Zootecnia, 24: 581-591, 2017.

SOUZA, A. H. et al. Effects of equine chorionic gonadotropin and type of ovulatory stimulus in a timed-AI protocol on reproductive responses in dairy cows. Theriogenology, 72: 10-21, 2009.

VASCONCELOS, J. L. M. et al. Reduction in size of the ovulatory follicle reduces subsequent luteal size and pregnancy rate. Theriogenology, 15: 307-314, 2011.

VASCONCELOS, J. L. M. et al. Evolution of fixedtime in dairy cattle in Brazil. Animal Reproduction Science, 12: 940-951, 2018. 